\title{
Application of Work Safety and Health Management Systems in the Technical Implementation Center of Primary Health Care Bendilwungu, Tulungagung, East Java
}

\section{Muhamad Taufiqurrahman ${ }^{1}$, Ratna Wardani ${ }^{1}$}

${ }^{1}$ Faculty of Public Health Institute of Health Sciences STRADA Indonesia

Email: mtrahman22@gmail.com

Received : October 10, 2020

Accepted : November 20, 2020

Published : November 30, 2020

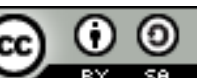

\begin{abstract}
Background. The Occupational Safety and Health Management System in Fasyankes is part of the overall Health Services Facility management system in the context of risk control related to work process activities in the Health Services Facility in order to create a healthy, safe, safe and comfortable work environment. The purpose of this research is to explore the implementation, evaluation process, impact and expectation of SMK3 in Primary Health Care Bendilwungu Tulungagung

Method. Based on the type of this research is a qualitative research to describe the implementation of SMK3 at Primary Health Care Bendilwungur. Another supporting instrument uses an instrument in the form of a list of questions containing semi-structured questions. The research informants numbered ten and four. Research Triangulation at the Puskesmas. Other tools used are friends, field notes, cellphones, then documented in the form of transcripts (field notes). Data processing was carried out by means of content analysis. Furthermore, it is reported and presented in a descriptive description in relation to the theory.

Results. The results of the study indicate that the application of SMK3 in the Primary Health Care Bendilwungu has been running from the end of 2018 as indicated by the existence of the SK Head of the Puskesmas as a guideline and legal umbrella in implementing the implementation of SMK3 in the Puskesmas. In the process of implementing and implementing SMK3 in the Puskesmas there are basic obstacles namely that there is no calm of K3 and SMK3 professionals and the joining of the SMK3 Implementation Unit with Patient Safety and the lack of knowledge and understanding of K3 and SMK3 to several Puskesmas employees.

Conclusion. The Primary Health Care Bendilwungu needs to improve its discrepancies in the application of SMK3 and provide training and guidance on K3 and SMK3 to employees so as to always improve the OHS work standard supervision at the Primary Health Care Bendilwungu and make K3 a work culture.
\end{abstract}

Keywords: Application of SMK 3, K3, and Puskesmas

Copyright (C) 2020 IIK STRADA Indonesia All right reserved.

This is an open-acces article distributed under the terms of the Creative Commons Attribution-ShareAlike 4.0 International License. 


\section{INTRODUCTION}

The era of globalization and the free market of the WTO and GATT which will take effect in 2020, Occupational Safety and Health is one of the prerequisites set out in the economic relations of trade in goods and services between countries that must be fulfilled by all member countries, including Indonesia. To anticipate this and realize the protection of the Indonesian working community, the 2010 Healthy Indonesia Vision has been established, which is a picture of Indonesian society in the future, whose people live in a healthy environment and behavior, obtain quality health services fairly and equally, and have a healthy degree of health. as high as possible (Ministry of Health RI, 2008).

The main objective of implementing an occupational health and safety management system is to prevent or minimize work and work accidents that can cause loss and damage to both material and physical work (Octopan et al., 2016).

Health service facilities are workplaces that have risks to the safety and health of human resources of health service facilities, patients, patient companions, visitors, and communities around health service facilities and that in the context of managing and controlling risks related to occupational safety and health In order to create conditions for health service facilities that are healthy, safe, secure and comfortable, it is necessary to organize occupational safety and health in health service facilities (Tana et al., 2013).

The preliminary study obtained from the results of interviews with PJ Quality at Bendilwungu Health Center which explains that the implementation of SMK3 has not been able to run according to government regulations or standards. Many factors influence and one of them is a lack of understanding of SMK3 itself. Puskesmas Bendilwungu, during the completion of puskesmas accreditation, tends to carry out improvement in quality and patient safety (PMKP) which is regulated by the Minister of Health of the Republic of Indonesia Regulation Number 44 of 2016 concerning Puskesmas Management Guidelines.

Competition and demands for international standards make occupational health and safety issues a global and very important issue. Many countries are increasingly raising their awareness of occupational safety and health (K3) issues related to labor protection issues and human rights as well as concern for the environment. The implementation of K3 management as part of the company's / agency's operational activities is a condition that cannot be ignored in order to achieve the required efficiency and productivity, in order to increase competitiveness (Fitriani \& Anik Setyo Wahyuningsih, 2017).

The Occupational Safety and Health Management System is an integral part of every management activity in a workplace institution or company, such as production management, human resource management, financial management and other management. The occupational safety and health management system is integrated with each existing management. Management is the ability or skills to obtain a result in order to achieve goals effectively and efficiently, through directing, mobilizing, and controlling activities carried out by people who are members of a cooperation unit. Meanwhile, a management system is a series of regular and interconnected management activities to achieve predetermined goals (Fitriana, 2015).

Occupational Health and Safety Management System according to Permenaker No. 05 of 1996 is part of the overall management system which includes organizational structure, planning, responsibilities, implementation, procedures, processes and resources needed for the development, implementation, achievement, review and maintenance of policies in order to control risks related to work activities. in order to create a safe, efficient and productive workplace. The five basic principles of the OSH Management System are a continuous cycle (Ministry of Manpower, 1996).

The Occupational Safety and Health Management System which is part of the overall management system which includes the organizational structure, planning, responsibilities, implementation, procedures, processes and resources required for the development, implementation, achievement, review and maintenance of OHS policies in the context of controlling risks. related to work activities in order to create a safe, efficient and productive workplace (MPU RI, 2008). According to the requirements of PP No. 50 of 2012 the elements of the K3 management system are as follows (Wulandani et al., 2015).

The Occupational Safety and Health Management System in Health Service Facilities, hereinafter referred to as SMK3 at the Health Care Facilities, is part of the overall Health Service Facility management system in the context of controlling risks related to work process activities in 
Health Service Facilities in order to create a healthy, safe, secure work environment. and comfortable (Ministry of Health, 2018).

\section{METHODS}

Researchers used a qualitative descriptive research method because this study explores the application of the Occupational Safety and Health Management System (SMK3) at the UPTD Puskesmas Bendilwungu, Kab. Tulungagung. Determination of informants with certain considerations, namely on the condition that those who become resource persons are employees or employees of the Bendilwungu Tulungagung Community Health Center and they are also structural officials at the Puskesmas, thus obtaining ten informants. To triagulate the determination with the Inclusion and Exclusion Criteria, there were four Triangulations that held policies in each unit, starting from UKM, Management of Puskesmas, Quality, and Head of Puskesmas. In addition, this research is also inductive and the results emphasize meaning. The use of purposive sampling in this study aims to be able to explore the implementation, Evaluation Process, Impact, and Expectations for the Implementation of the Occupational Safety and Health Management System (SMK3) at the UPTD Puskesmas Bendilwungu Tulungagun Regency

Samples in qualitative research are not named as respondents, but as sources, or participants, informants, friends and teachers in the study(Sugiyono, 2015). The informants in this study were employees or employees who worked at the Bendilwungu Tulungagung Health Center and were willing to become informants for in-depth semi-structured interviews (indept interview). The types of data collected in this study are primary data and secondary data. For crosschecks, it is carried out at the Head of the Bendilwungu Tulungagung Health Center. Secondary data were obtained from observation and documentation in the form of recording written data located at the research site, namely in the working area of Puskesmas Bendilwungu Tulungagung.

The sampling technique in this study used purposive sampling to determine the sample with certain considerations, namely on the condition that those who become resource persons are employees or employees at Bendilwungu Tulungagung Health Center and they are also structural officials at Bendilwungu Tulungagung Health Center. Researchers give questions at least 3 times in a row to produce a saturation point with the same answers from each informant, only informants who conducted semi-structured interviews answered consistently.

\section{RESULTS}

The results of the study show that the implementation of SMK3 at Bendilwungu Health Center has been running since the end of 2018 which is indicated by the SK Head of the Puskesmas as a guideline and legal umbrella in implementing SMK3 implementation at Puskesmas. In the process of implementing and implementing SMK3 at Puskesmas there are basic obstacles, namely there is no professional K3 and SMK3 calm and there is still a joining of the SMK3 Implementation Unit with Patient Safety and there is still a lack of knowledge and understanding of K3 and SMK3 to some Puskesmas employees.

These are some of the results of interviews with research informants who describe the Implementation, Evaluation Process, Impact, and Expectations for the Implementation of the Occupational Safety and Health Management System (SMK3) at the UPTD Puskesmas Bendilwungu Tulungagung Regency.

1. How is the implementation of the SMK3 Occupational Health and Safety Management System at the Bendilwungu Health Center UPTD? (Policy Determination, SMK3 Planning)

"It has been running until now, although not all of them are the same as SMK3 in general, because they still apply Patient Safety before SMK3 runs. SMK3 is still new in mid-2018 towards the end while the Puskesmas has accreditation in 2017 so it has not fully applied SMK3 but from the Puskesmas it is still trying to make the safety system in the Puskesmas the best and also follows the applicable laws as a guide for its implementation "Informant 3

2. What hinders the process of implementing an Occupational Health and Safety Management System (SMK3) at the Bendilwungu Puskesmas UPTD? (Decision Making, Outreach to Public Health Center HR) 
"There is still a lack of understanding of SMK3 and Patient Safety even though SOPs already exist in every room and it seems that there is a lack of supervision from the Quality Team for standardization that is already in effect and running at the Puskesmas" informant 2

3. How are efforts to reduce barriers to the implementation of an Occupational Health and Safety Management System (SMK3) at the Bendilwungu Health Center UPTD? (Risk Management, Legal Regulations, and Completeness of Facilities)

"To reduce the obstacles itself, there are quite a lot of Puskesmas, starting from existing infrastructure, updating new systems or new developments. Even though they often participate in training or seminars in order to maintain the quality of existing services. Not all of them understand about the safety system and about the danger signs that exist, especially in the field of K3. So it took a while to respond quickly. "Informant 3

4. What supports the implementation of the Occupational Safety and Health Management System (SMK3) at the Bendilwungu Health Center UPTD? (Standard requirements for SMK3 and SMD Professional in their fields)

"Employees here always support all work programs of the Puskesmas because it is a form of employee commitment to carry out work or tasks. Puskesmas employees always learn about changes or new policies in existing Puskesmas. That includes the form of employee support for technical and implementation "informants 5

5. What is the impact of the process of implementing an occupational safety and health management system (SMK3) at the Bendilwungu Puskesmas UPTD? (Performance Improvement in Planning, Implementation, Monitoring and Evaluation)

"It has a very big impact. There are many differences from Patient Safety which was previously applied with SMK3. More detailed in all aspects. everything must be updated from the SOP, safety signs and importantly, there must be someone who is certified or competent in their field. Like what I did in the field, AK3 was generally lacking, "informant3

6. How is the evaluation process for the Implementation of Occupational Health and Safety Management Systems (SMK3) at the Bendilwungu Health Center UPTD? (SMK3 Examination, Testing, Measurement, and Audit)

"Usually, the evaluation is carried out from monitoring which activities have problems and what are lacking. From there everything is recorded and reported to the PJ in the field in Mutu after that each PJ makes a brief report to be reported to the Head of Quality for follow-up. before the follow-up, usually the internal meeting of PJ and Kelapa Mutu, after that, the Puskesmas internal meeting so that all data and policies run well and the process is faster. "

7. What are your hopes for the process of implementing an occupational safety and health management system (SMK3) at the Bendilwungu Community Health Center UPTD?

"The running of SMK3 at the Puskesmas together with all who follow it, such as those from experts in their fields, technical equipment in the field. Reporting to implementation in the evaluation runs in accordance with the Puskesmas Head's Decree for safety and comfort at the Puskemas for customers or Puskesmas employees themselves and a quick response in evaluations and follow-up to maintain SMK3 at the Puskesmas. always coordinate with all teams so that all obstacles can be resolved properly and quickly in the system or in the field itself "informant4

\section{DISCUSSION}

1. How is the implementation of the SMK3 Occupational Health and Safety Management System at the Bendilwungu Health Center UPTD? (Policy Determination, SMK3 Planning)

The implementation of SMK3 in Puskesmas has been running at the end of 2018 with the decision of the Puskesmas Head's Decree as a legal basis or work guideline for Puskesmas employees. Prior to the implementation of SMK3, Puskesmas Bendilwungu had implemented this Patient Safety which made employees not completely separated from SOPs and old habits when doing work and actions in the field. Puskesmas employees have not entirely implemented SMK3 in Puskesmas because they need to adapt to the implementation in the field and the infrastructure is still inadequate according to SMK3 standards.

Based on the aforementioned matters, it is necessary to increase efforts for occupational safety and health at the health facilities. In addition, based on statutory regulations, there is a right for everyone to get protection against the risk of occupational accidents and occupational diseases, 
as well as for the human resources of the health facilities, patients, patient companions, visitors, and the community around the health facilities. With the enactment of this Regulation of the Minister of Health, it is hoped that the health facilities can carry out K3 at the health facilities on an ongoing basis so that the goals of occupational safety and health efforts can be achieved properly (Ministry of Health, 2018).

An overview of the application of SMK3 at Bendilwungu Health Center

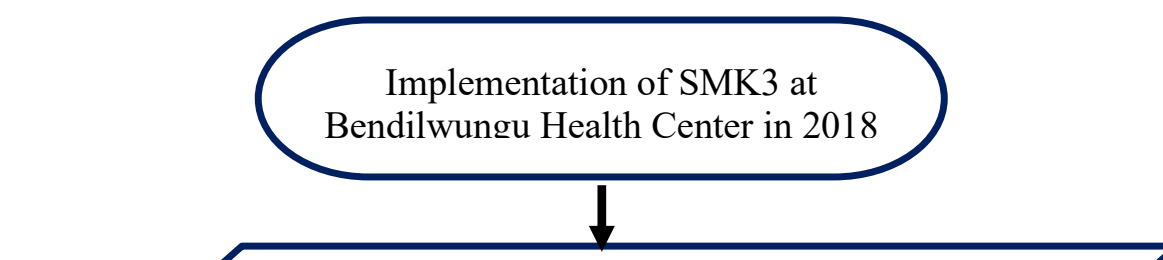

1. Prioritizing service needs even though not all have been fulfilled

2. Do our best to keep all units running

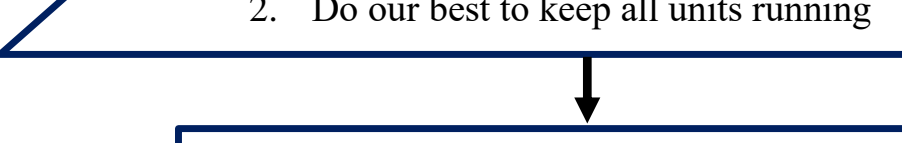

Not yet systematic, lack of attention and follow-up from the field

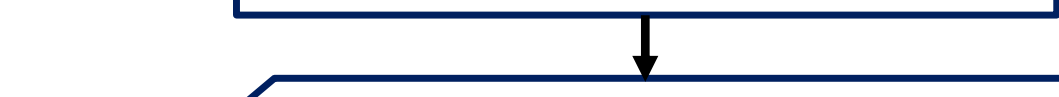

1. Gradually in the procurement of infrastructure

2. Synchronize all regulations for the

1. The operation of SMK3 is in accordance with the SOP and the Law

2. Has general $\mathrm{K} 3$ and AK3 professional

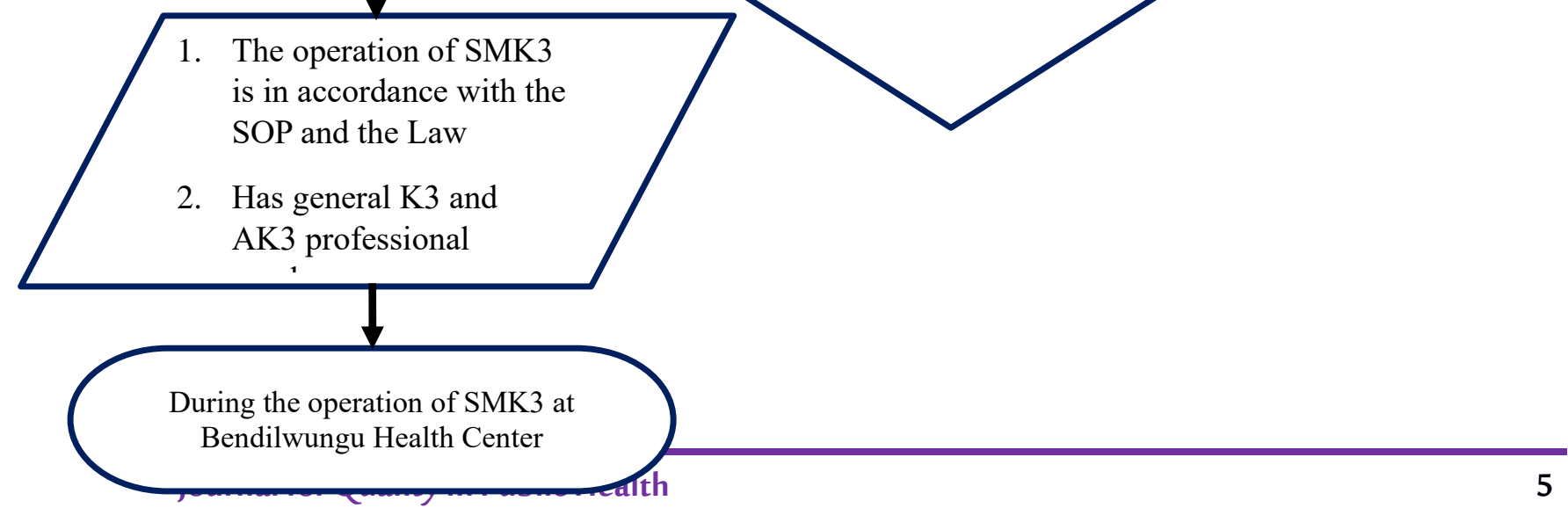

1. Infrastructure, new system updates and info on SMK3 developments

2. Participated in training and seminars

Delivering the results of the internal audit findings to the Head of the Puskesmas, the person in charge of quality management, the person in charge of the program and as a basis for making improvements 
Puskesmas Bendilwungu strives for the best in service for customers and employees of the Puskesmas. In line with 2010 n improvement and service act Picture 1 Flowchat of Research Results esmas Bendilwungu has changed the previous Puskesmas management system to SMK3 Fasyankes, this change creates new adaptations in the Puskesmas system which are coordinated with other units and divisions. The operation of SMK3 in the Puskesmas is a good development for the Puskesmas and gradually the facilities that do not meet the SMK3 standards are replaced or updated to fit the prevailing systems and regulations. Compared to the best efforts of the Puskesmas, not all employees understand and understand the basics of K3 and SMK3 that apply at the Puskesmas.

2. What hinders the process of implementing an Occupational Health and Safety Management System (SMK3) at the Bendilwungu Puskesmas UPTD? (Decision Making, Outreach to Public Health Center HR)

The obstacles at the Puskesmas are more related to the system and actions of fellow employees in the field. This is still an adaptation stage from changing Patient Safety to SMK3 or also not understanding how K3 and SMK3 work itself, so that is what makes follow-up from the field still not achieving the achievement targets that were previously planned.

The bottlenecks of the occupational safety and health management system are divided into several points. These points are that there are no requirements from consumers regarding proof of the implementation of an occupational safety and health management system. The impact of the economic crisis can also hinder the creation of an occupational safety and health management system. There are no consequences for companies that delay and refuse the implementation of an audit of the occupational safety and health management system. The lack of readiness of companies, especially hospitals due to company ignorance and audit fees that are considered burdensome to the company. The framework for the coordination of the audit implementation of other engineering departments has not yet been realized(Ramli, 2010)

The obstacle of SMK3 at Bendilwungu Health Center is that the implementation of SMK3 has been going well and the maximum effort is in its application and implementation, which is the problem in Puskesmas that there are no employees who really understand about K3 and SMK3 themselves. it becomes a problem when following up in the field or disseminating new policies or rules to other employees.

The Head of the Puskesmas strives for the implementation of SMK3 still running with policies and rules that support SMK3 itself and what happens in the field is still not optimal or has not reached the target achievement expected by the Puskesmas for service to its own customers and employees

3. How are efforts to reduce barriers to the implementation of an Occupational Health and Safety Management System (SMK3) at the Bendilwungu Health Center UPTD? (Risk Management, Legal Regulations, and Completeness of Facilities)

Starting from the existing infrastructure, new system updates or new development information. Often participate in training and seminars in order to maintain the quality of existing services. It takes more time for employees to be more efficient in implementing SMK3 at Puskesmas.

The aim of SMK3 is to create an integrated occupational safety and health system in preventing and reducing occupational accidents and diseases as well as creating a healthy, safe, efficient and productive workforce. (Soputan et al., 2014)

Efforts to overcome the obstacles of SMK3 at Bendilwungu Health Center are the existence of a very clear legal umbrella as a work guideline and with good implementation it can be optimized in the work system and technical implementation in the field itself and respond well according to the directions requested by the Puskesmas leadership. Employees at the Puskesmas do not yet fully understand SMK3 and understand its implementation. From the description above, it can have an unfavorable impact on existing services at the Puskesmas.

The Puskesmas itself tries to include K3 and SMK3 training for employees in the Bandi test to other Puskesmas that have implemented SMK3 because of limited costs making everything optimized as possible in implementing and planning SMK3 at Bendilwungu Health Center. 
4. What supports the implementation of the Occupational Safety and Health Management System (SMK3) at the Bendilwungu Health Center UPTD? (Standard requirements for SMK3 and SMD Professional in their fields)

Employees here always support all work programs from the Puskesmas because it is a form of employee commitment to carry out work or tasks. Puskesmas employees always learn about changes or new policies in existing Puskesmas. Including the form of employee support for technical and implementation. That is one of the things that supports the implementation of SMK3 in Puskesmas and also in Bendilwingu which has the motto "serve wholeheartedly". Bendilwungu Community Health Center and its employees are trying to provide the best service to customers and patients at the Puskesmas.

Regarding occupational safety requirements, including preventing and controlling the occurrence of occupational diseases, both psychological and physical, poisoning, infection and transmission, providing self-help equipment to workers, providing adequate air refreshment, obtaining harmony between labor, work equipment, environment, how it works, and the work process. (MINISTRY, 1970)

Supporting the implementation of SMK3 at Bendilwungu Health Center is to carry out all duties and directions from the Head of the Puskesmas for the implementation of SMK3. Already describing the support of employees for the implementation of SMK3 in the Puskesmas and seeing all the facilities and infrastructure of the Puskesmas that support the implementation of SMK3 are reviewed to find out whether they have met the SMK3 criteria and the results are very surprising that many have not entered the SMK3 criteria. here Puskesmas Bendilwungu strives so that all needs can run and there is no decrease in the quality of service to Puskesmas customers.

Human Resources at Bendilwumgu Health Center are very competent in their respective fields, but unfortunately the implementation of SMK3 is still combined with Patient Safety and PPI at the Puskesmas. This is what makes SMK3 run without a professional in their field, namely General AK3 or having K3 Awerness Management Certification or what is better known as SMK3 so that all tasks and directions run according to SMK3 criteria, not only seeing the direction of the SK and laws then implementing SMK3 at the Puskesmas .

5. What is the impact of the process of implementing an occupational safety and health management system (SMK3) at the Bendilwungu Puskesmas UPTD? (Performance Improvement in Planning, Implementation, Monitoring and Evaluation)

During the adaptation period, the changes from Patient Safety to SMK3 were many changes and including an increase in work safety which had a good impact on the Puskesmas. Therefore, the employees are very well welcomed because they can help in the new accreditation process at the Bendilwungu Community Health Center which adds even greater service capacity, namely the addition of an emergency room. The Puskesmas and the employees themselves are more optimal than before for the improvement of new parasana facilities in supporting SMK3 at Bendilwungu Health Center

The Occupational Safety and Health Management System in Health Service Facilities, hereinafter referred to as SMK3 at the Health Care Facilities, is part of the overall Health Service Facility management system in the context of controlling risks related to work process activities in Health Service Facilities in order to create a healthy, safe, secure work environment. and comfortable. (Ministry of Health, 2018)

The impact of the implementation of SMK3 at Bendilwungu Health Center is very impactful and very pronounced in the implementation of SMK3 in Puskesmas, starting from the discipline, obeying SOPs and employee commitment to implementing SMK3. This explains that employees are very open to new things and are trying to optimize their time for adaptation to the implementation of SMK3 at Bendilwungu Health Center.

Monitoring and evaluation are running as they should be, as well as a new system for handling that is more optimal and faster to see what efforts should be made for field implementation in achieving targets or existing work assignments. And all service units are connected to each other and make it easier to coordinate with other units to prevent technical miscommunication in the field. 
6. How is the evaluation process for the Implementation of Occupational Health and Safety Management Systems (SMK3) at the Bendilwungu Health Center UPTD? (SMK3 Examination, Testing, Measurement, and Audit)

Usually the evaluation is carried out from monitoring which activities have problems and what are lacking. From there everything is recorded and reported to the PJ in the field in Mutu after that each PJ makes a brief report to be reported to the Head of Quality for follow-up. Before the follow-up, usually the PJ and Kelapa Mutu internal meetings, after that, the Puskesmas internal meeting so that all data and policies run well and the process is faster and what is the solution so that all of the ASEPs run well even though slowly because of the distribution of the program so that it runs well too.

The first thing to do when monitoring is to check in accordance with the provisions. Reporting or documentation will then be used as material for further evaluation. Occupational safety and health inspections are currently very necessary and effective in terms of efforts to promote occupational safety and health in the field.(OHSAS, 2007)

As for my opinion on the SMK3 evaluation process at Bendilwungu Community Health Center is how systematic performance in all other unit areas makes it easier to crosscheck existing obstacles and be faster in handling follow-up for existing problems. All monitoring and evaluation activities starting from data collection, inspection and review are in internal audit supervision to provide easier space for reporting problems or findings that occur in the field to the Head of the Puskesmas to see how work and achievements are as well as what hinders the implementation process. giving decisions or policies and always directing better processes.

7. What are your hopes for the process of implementing an occupational safety and health management system (SMK3) at the Bendilwungu Community Health Center UPTD?

The operation of SMK3 is in accordance with the existing SOP or law guidelines and is always developing to maintain its own work safety and health. Standardization in all units so that they are well connected and the work system runs properly. Completeness of existing facilities and infrastructure are submitted gradually so that everything is in accordance with SMK3 standards, and the best is for Puskesmas.

Increasing the completeness of facilities and infrastructure to support employee performance and services as well as the running of the system and always being well coordinated and cooperating in systems related to SMK3 and other fields. Creating a sense of security and comfort for customer service. All problems can be resolved quickly and coordinated to make the Puskesmas the best within the scope of the Puskesmas and outside.

8. Findings of new themes in the application of SMK3 at Bendilwungu Puskesmas UPTD

From the results of the study, it was found that the implementation of SMK3 at Bendilwungu Health Center had actually been running from the end of 2018 and until now it is still in the compilation stage and completing the operational needs of the Puskesmas in implementing SMK3 at Bendilwungu Community Health Center. As the implementation of SMK3 in Puskesmas progressed, there were obstacles that slowed down the achievement of Puskesmas service targets over day from before. From the implementation side, it runs as usual without any obstacles in the part of the infrastructure that must be fulfilled in field activities because it supports the services of the Puskesmas. All existing directions from the Head of Puskemas can be socialized well to all employees, only there are still employees who really do not understand $\mathrm{K} 3$ and understand the SMK3 work system.

Puskesmas Bendilwungu has employees who are very professional in their fields and SMK3 in Puskesmas still do not have experts or professionals in the field of K3. This is also a factor why SMK3 still have problems in the technical field or in the system. Because while still relying on the knowledge and direction of the SK or the mandate of the law in the application and implementation of SMK3 at Bendilwungu Health Center.

\section{CONCLUSION}

Puskesmas Bendilwungu improves and maintains the implementation of SMK3 in Puskesmas by continuing to carry out hazard identification, monitoring and assessment as well as conducting internal audits, the results of which can be used in establishing work procedures at Puskesmas Bendilwungu and also increasing work productivity of employees at Puskesmas. In addition, 
Puskesmas Bendilwungu needs to make improvements to the mismatch in the application of SMK3 and provide training and guidance on $\mathrm{K} 3$ and SMK3 to employees so that they always improve supervision of K3 work standards at Bendilwungu Health Center and make K3 a work culture.

\section{REFERENCES}

Fitriana, L. (2015). Implementation of the Occupational Health and Safety Management System (Smk3) at Pt Ahmadaris, Tegal Regency, 2015.

Fitriani, L., \& Anik Setyo Wahyuningsih. (2017). Implementation of Occupational Health and Safety Management Systems (Smk3) At Pt. Ahmadaris. Journal of Public Health Research and Development, 1 (1), 29-35. http://journal.unnes.ac.id/sju/index.php/higeia\%0A

Ministry of Health. (2018). REGULATION OF THE MINISTER OF HEALTH OF THE REPUBLIC OF INDONESIA NUMBER 52 OF 2018 CONCERNING OCCUPATIONAL SAFETY AND HEALTH IN HEALTH SERVICE FACILITIES. 1, 430-439.

Ministry of Manpower. (1996). Occupational Health and Safety Management System. Permenaker Number 5.

Ministry of Health RI. (2008). Minister Of Health Of The Republic Of Indonesia Number: 129 / Menkes / SK / II / 2008 Concerning Minimal Hospital Services Standard Minister Of Health Of The Republic Of Indonesia. In Supplement Number State Gazette Number 4355 Supplement Number State Gazette Number 4400. https://doi.org/10.1017/CBO9781107415324.004

Octopan, G., Carlo, N., \& Khaidir, I. (2016). Implementation of Occupational Health and Safety Management Systems (SMK3) in the Block III Presidential Market Development Project in Padang City. Journal of Civil Engineering and Planning.

Sugiyono. (2015). Research methods. Research methods. quantitative, qualitative, and R\&D research methods, Alfabeta, cv. (2016).

Tana, L., Suharyanto Halim, F., Lisdawati, V., Emiliana Tjitra, and, Applied Technology for Health and Clinical Epidemiology, P., Litbangkes, B., \& Biomedical and Basic Health Technology, P. (2013). Implementation of Occupational Health and Safety in Health Centers in Three Provinces in Indonesia. Implementation of Occupational Health and Safety in Primary Health Care in Three Provinces of Indonesia. Health Research Bulletin, 2-5.

Wulandani, CD, Wardani, MK, \& Harianto, F. (2015). Evaluation of the Implementation of the Occupational Safety and Health Management System (SMK3) in the Gunawangsa MERR Surabaya Apartment Construction Project. National Seminar on Applied Science and Technology III 2015 Adhi Tama Institute of Technology Surabaya, ISBN 978-602-98569-1-0, 773-780. 